\title{
Regional Substrates of the Brazilian Northeast on Acclimatization and Development Morphological of Minirose
}

\author{
David Correia dos Anjos ${ }^{1}$, Gabrielen de Maria Gomes Dias ${ }^{2}$, Fernando Felipe Ferreyra Hernandez ${ }^{1}$ \\ \& Josefa Diva Nogueira Diniz ${ }^{3}$ \\ ${ }^{1}$ Departamento de Ciências do Solo, Universidade Federal do Ceará, Fortaleza, CE, Brazil \\ ${ }^{2}$ Instituto de Desenvolvimento Rural, Universidade da Integração Internacional da Lusofonia Afro-Brasileira, \\ Redenção, CE, Brazil \\ ${ }^{3}$ Departamento de Fitotecnia, Universidade Federal do Ceará, Fortaleza, CE, Brazil \\ Correspondence: David Correia dos Anjos, Departamento de Ciências do Solo, Universidade Federal do Ceará, \\ Fortaleza, CE, Brazil. Tel: 55-85-987-775-247. E-mail: dav_correia@hotmail.com
}

Received: March 20, 2018

Accepted: April 28, $2018 \quad$ Online Published: May 15, 2018

doi:10.5539/jas.v10n6p341

URL: https://doi.org/10.5539/jas.v10n6p341

The research is financed by BNB (Bank Northeast of Brazil) and CNPq (National Council for Scientific and Technological Development).

\begin{abstract}
The transition from heterotrophism to autotrophism in acclimatization is a delicate process for most species. The objective of this work was to evaluate combinations of regional substrates of the Brazilian Northeast in the acclimatization and morphological development of minirose (Rosa chinensis 'Minima') seedlings. The experiment was carried out in a greenhouse using seedlings with 30 days of in vitro culture. The treatments were constituted by: 1) dry coconut powder; 2) $75 \%$ dry coconut powder $+25 \%$ rice husk; 3) $50 \%$ dry coconut powder $+50 \%$ rice husk; 4) $75 \%$ dry coconut powder $+25 \%$ charcoal rice husk; 5) $50 \%$ dry coconut powder + $50 \%$ carbonized rice husk; 6) $100 \%$ vermiculite; 7) $50 \%$ vermiculite $+50 \%$ dry coconut powder; 8) commercial substrate; 9) $75 \%$ sand $+25 \%$ dry coconut powder and 10) $50 \%$ sand $+50 \%$ dry coconut powder. After 21 days, the following characteristics were evaluated: survival percentage, leaf number, shoot height, dry matter of shoot and root and total dry matter. The regional materials tested showed a good choice of substrates to be used in the acclimatization of minirose seedlings. The vermiculite presented the worst results in the characteristics evaluated. Dry coconut powder as substrate should be used in mixtures with other materials to provide better acclimatization conditions. The use of $50 \%$ dry coconut powder $+50 \%$ rice husk provided a best development and growth of minirose seedlings (Rosa chinensis 'Minima') than other tested substrates
\end{abstract}

Keywords: ex vitro adaptation, rice husk, in vitro seedlings, dry coconut powder

\section{Introduction}

The agribusiness of flowers and ornamental plants has great economic and social importance, as it values the agricultural activity generating employment, and income for micro and small producers throughout the Country, incorporating important parcels of rural female work. In addition to protecting the environment, the use of many residues as inputs (fertilizers and substrates) (Mitsueda et al., 2011; Junqueira \& Peetz, 2014).

In Brazil, there is an increase in the demand for the production of plants in ecologically correct containers and substrates favoring the use of agroindustrial residues as substrates that contribute to the reduction of production costs and to the use of residues whose disposal in the environment represents a great negative impact (Lopes, 2011). In this way, some agroindustrial residues such as rice husk, dry coconut powder, fruit peels and cultural residues have been tested to be used as substrates (Lopes, 2011; Rota \& Pauletti, 2008).

The manipulation of various organic and inorganic materials, usually in mixtures of two or more components that vary only the objective, has been used in the elaboration of substrates for the production of seedlings (Fermino et al., 2010). However, it is necessary to be aware of the substrates used in the production of seedlings, since they must present chemical and physical characteristics that are ideal for growth (Klein et al., 2012; Klein, 
2015). Considering also, that the properties of the substrates vary according to their origin (Kratz et al., 2013), search for alternatives low cost as substrates composed primarily of organic wastes from the available of the material in the region (Dutra et al., 2012).

The minirose, a native species of China (Rosa chinensis Jacq) are traditionally multiplied by vegetative propagation which favors the spread and accumulation of pathogens. It is also influenced by the time of year and the low multiplication rate, which limit conventional propagation (Diniz et al., 2014). Some researchers have been successful in the multiplication and rooting of minirose explants in vitro with the aid of micropropagation, which allows rapid multiplication of species from a single individual, at any time of the year, with greater control over the health of the propagated material (Thakur \& Karnosy, 2007).

Due to the great environmental difference between in vitro and ex vitro cultivation, acclimatization of plants is one of the essential points in obtaining micropropagated seedlings (Ferreira et al., 2014). For Silva et al. (1995), the production of micropropagated minirose seedlings needs to be overcome in the acclimatization phase, which is limiting to the success of seedlings production by in vitro cultivation, because at this stage they undergo stresses that can culminate in deep damage or even plants.

Therefore, substrates used in ex vitro acclimatization directly influence the growth and development of micropropagated seedlings through their physical, chemical and biological characteristics. Given the above, the objective of this work was to evaluate the use of different combinations of regional substrates as alternatives in the acclimatization and development of micropropagated mininose (Rosa chinensis 'Minima') seedlings.

\section{Material and Methods}

The experiment was carried out under greenhouse conditions, located in the Soil Science Department of the Federal University of Ceará (UFC) in the city of Fortaleza, CE, with an altitude of $47 \mathrm{~m}$, South latitude $3^{\circ} 44^{\prime} 35^{\prime \prime}$ and longitude West $38^{\circ} 34^{\prime} 33^{\prime \prime}$. A mean luminosity of 2500 Lux was recorded during the experiment, and the mean values of maximum and minimum temperatures and humidity recorded with the aid of the thermohygrometer data logger in the period were: $26 \pm 2{ }^{\circ} \mathrm{C}$ and $36 \pm 2{ }^{\circ} \mathrm{C}$, respectively, with relative humidity between 40 and $85 \%$.

\subsection{Plant Material and Growing Condition}

At the Tissue Culture Laboratory of the Plant Science Department of the Federal University of Ceará, seedlings minirose (Rosa chinensis 'Minima') were grown in used in the MS cultivation medium (Murashigue \& Skoog, 1962) and rooting for 30 days, for later acclimatization.

The seedlings were removed from the flasks and washed in running water to eliminate all the culture medium adhered to the roots. Uniform seedlings with approximately $10 \mathrm{~cm}$ height were selected and transferred to G-18 boxes, with the substrate moistened with nutrient solution.

\subsection{Preparation of Substrates}

The treatments consisted of 10 substrates of which 7 were made into mixtures, 2 of pure materials (dry coconut powder and vermiculite) and 1 commercial (Table 1).

Table 1. Composition of the substrates according to each treatment

\begin{tabular}{ll}
\hline Treatment & Description \\
\hline $\mathrm{DCP}$ & Dry coconut powder \\
$75 \% \mathrm{DCP}+25 \% \mathrm{RH}$ & Dry coconut powder + Rice hull $(3: 1)$ \\
$50 \% \mathrm{DCP}+50 \% \mathrm{RH}$ & Dry coconut powder + Rice hull $(2: 2)$ \\
$75 \% \mathrm{DCP}+25 \% \mathrm{CRH}$ & Dry coconut powder + Carbonized rice husk $(3: 1)$ \\
$50 \% \mathrm{DCP}+50 \% \mathrm{CRH}$ & Dry coconut powder + Carbonized rice husk $(2: 2)$ \\
$100 \% \mathrm{~V}$ & Vermiculite \\
$50 \% \mathrm{~V}+50 \% \mathrm{DCP}$ & Vermiculite + Dry coconut powder $(2: 2)$ \\
$\mathrm{B}$ & Bioplant $\left({ }^{\circledR}(\right.$ comercial) \\
$75 \% \mathrm{R}+25 \% \mathrm{DCP}$ & River washed sand + Dry coconut powder $(3: 1)$ \\
$50 \% \mathrm{R}+50 \% \mathrm{DCP}$ & River washed sand + Dry coconut powder $(2: 2)$ \\
\hline
\end{tabular}

The dry coconut powder used was washed with well water until it reached an electrical conductivity of 0.2 
$\mathrm{dS} \mathrm{m}^{-1}$. The carbonized rice husk was prepared using an equipment known as carbonizer. The vermiculite of medium granulometry $(1-2 \mathrm{~mm})$ was used, according to the manufacturer's specifications. The washed river sand was sieved with a $2 \mathrm{~mm}$ sieve to remove larger particles that could impair seedling development. The commercial substratum Bioplant ${ }^{\circledR}$ used is a product composed of pine bark, aggregating agents, vermiculite, coconut fiber and mineral complements (NPK more micronutrients). The chemical characteristics of the product include $\mathrm{pH}$ between 5.2-6.5 and EC between $0.6-3.2 \mathrm{mS} \mathrm{cm}^{-1}$. With the exception of vermiculite and the commercial substrate, all others underwent $30 \mathrm{~min}$ for autoclaving.

\subsection{Nutrition Solution}

All substrates, except the commercial substrate, were immersed for 24 hours in nutrient solution with 8.0; $0.41 ; 7.5 ; 1.50 ; 4.0$ and $5.0 \mathrm{mg} \mathrm{L}^{-1}$ of $\mathrm{N}, \mathrm{P}, \mathrm{K}, \mathrm{Ca}, \mathrm{Mg}$, and $\mathrm{S}$, respectively, prepared with $\mathrm{NH}_{4} \mathrm{NO}_{3}, \mathrm{KNO}_{3}$, $\mathrm{KH}_{2} \mathrm{PO}_{4}, \mathrm{CaCl}_{2}$ and $\mathrm{MgSO}_{4}$ and $1.2 ; 1.1 ; 0.4 ; 0.2 ; 0.03$ and $0.01 \mathrm{mg} \mathrm{L}^{-1}$ of $\mathrm{Fe}, \mathrm{Mn}, \mathrm{Zn}, \mathrm{B}, \mathrm{Cu}$ and $\mathrm{Mo}$, respectively prepared with Fe-EDTA, $\mathrm{MnSO}_{4} \cdot \mathrm{H}_{2} \mathrm{O}, \quad \mathrm{ZnSO}_{4} \cdot 7 \mathrm{H}_{2} \mathrm{O}, \quad \mathrm{H}_{3} \mathrm{BO}_{3}, \quad \mathrm{CuSO}_{4} \cdot 5 \mathrm{H}_{2} \mathrm{O}$ and $\mathrm{Na}_{2} \mathrm{MoO}_{4} \cdot 2 \mathrm{H}_{2} \mathrm{O}$.

\subsection{Transplanting of Seedlings}

After 24 hours of immersion, the substrate was manually compressed to remove excess moisture and placed in transparent G-18 type plastic boxes to perform the transplanting.

After transplantation, the boxes were sealed with plastic insulfilme (Figure 1E). After transplanting, the experimental units (boxes G-18 with 12 seedlings) were placed in a greenhouse for 21 days, at which time the evaluations were carried out. The following variables were evaluated: survival percentage (SP) calculated by the formula: [SP $=($ Number of surviving plants (NSP)/Total number of transplanted plants $(\mathrm{TNP}) \times 100$; ; Number of leaves (NL); Height of seedlings (cm) (HS); Dry matter of aerial part (g) (DMAP) and roots (g) (DMR); Total dry matter (TDM) was obtained by adding DMAP and DMR. A millimeter rule, a digital analytical balance and a forced circulation greenhouse were used for the evaluations.

\subsection{Statistical Analysis}

The design was a completely randomized design with 10 treatments and 4 replicates per treatment, to evaluate the acclimatization and the development of the micropropagated seedlings in different substrates formulated with regional materials.

All evaluated characteristics were submitted to analysis of variance (ANOVA) and their means were compared by the Tukey test at the $1 \%$ probability level. All statistical analyzes were performed using the SAEG software (SAEG, 2007).

\section{Results and Discussion}

According to the characteristics evaluated, the substrates used significantly influenced the significance level of $1 \%$ by the $\mathrm{F}$ test, percentage of survival (SP), leaf number (NL), height of seedling (HS) and dry matter root (DMR). For the dry matter of the aerial part (DMAP) and total dry matter (TDM), the substrates significantly influenced the level of significance of $5 \%$ by the $\mathrm{F}$ test (Table 2).

Table 2. Summary of variance analysis for percentage of survival (PS), leaf number (NL), seedling height (HS), dry matter of aerial part (DMAP), root dry matter (DMR) and total dry matter (TDM) in the acclimatization of micropropagated minirose seedlings on different substrates

\begin{tabular}{llllllll}
\hline \multirow{2}{*}{ Source of variation } & \multirow{2}{*}{ G.L. } & \multicolumn{5}{c}{ Medium Square } \\
\cline { 3 - 8 } & & OS & NL & HS & DMAP & DMR & TDM \\
\hline Treatments & 9 & $791.85^{* *}$ & $28.032^{* *}$ & $5.081^{* *}$ & $0.048^{*}$ & $0.008^{* *}$ & $0.069^{*}$ \\
Residue & 30 & 108.21 & 9.057 & 1.463 & 0.019 & 0.002 & 0.028 \\
\hline
\end{tabular}

Note. $* *=$ significant at $1 \%$ probability by $\mathrm{F}$ test; $*=$ Significant at $5 \%$ probability by test $\mathrm{F}$.

At acclimatization of minirose seedlings in G-18 boxes inallowed a high percentage of survival in all substrates, with values ranging from $60.45 \%(100 \%$ vermiculite) to $100 \%(50 \%$ dry coconut powder $+50 \%$ carbonized rice husk) (Figure $1 \mathrm{~F}$ and Table 3). Low plant survival during acclimatization may occur due to high water loss (dehydration) during the period of this phase (Schuck et al., 2012). In addition, the leaves were small and thin and the root system was poorly developed, possessing low amounts of trichomes and photoautotrophic activity 
(Iarema et al., 2012). Demonstrating that for certain species the use of alternatives in the acclimatization phase promotes good results for the survival of the plants produced by the tissue culture technique.

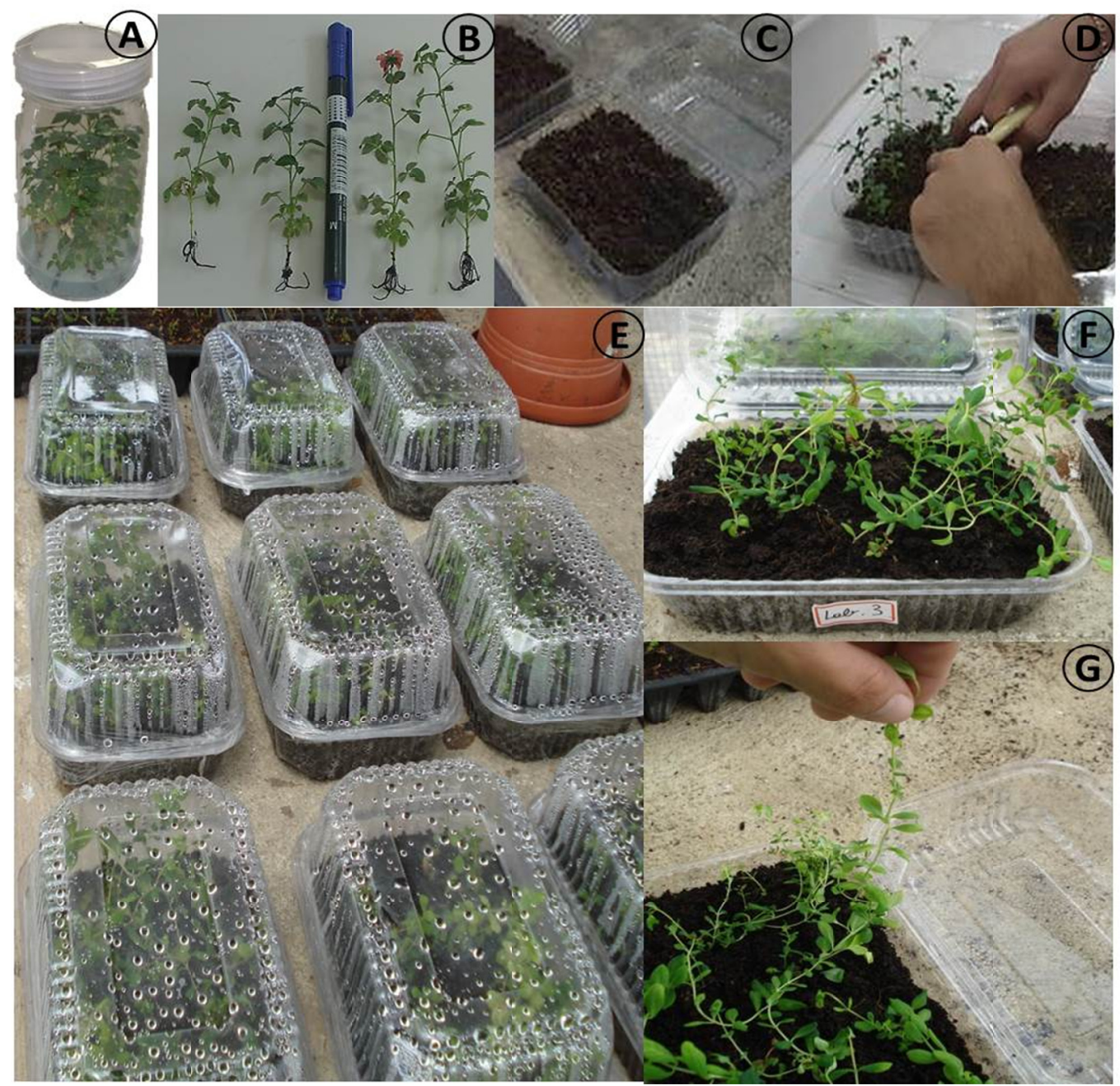

Figure 1. Stages of the acclimatization process of minirose seedlings (Rosa chinensis 'Minima'). A) Micropropagated seedlings with 30 days of rooting. B) Removal of the seedlings from the bottles for transplanting. C) Plastic box type G-18 with substrate. D) Manual transplanting of seedlings. E) Conditioned seedlings in boxes and moistened with nutrient solution in a greenhouse. F) and G) seedlings after 21 days of acclimatization

The percentage of plant survival during acclimatization was higher on substrates where the dry coconut powder was mixed in the proportions $50 \%$ and $75 \%$ with carbonized rice husk. However, there were no significant differences in treatments in which $75 \%$ and $50 \%$ dry coconut powder was mixed with washed river sand and with vermiculite presenting $85.4 \%$ and $83.3 \%$ survival percent, respectively. There was also no statistical difference of these treatments when using the Bioplant ${ }^{\circledR}$ substrate in which there was $83.3 \%$ of plant survival. In the substrates where pure dry coconut powder or mixed with uncured rice husk and vermiculite were used, the percentage of survival ranged from 60 to $72.9 \%$, and they differed statistically from those treatments in which the husk of carbonized rice. The transfer of in vitro conditions with high humidity, ex vitro with low humidity, among other factors, results in plant losses, due to drying and the lower growth of those that survive (Braga et al., 2011).

Although no statistical difference of these treatments was observed, the vermiculite substrate showed the lowest percentage of plant survival. Already the best behavior of the substrates with carbonized rice husk can be attributed to the increase of the silica content, which serves as an antifungal agent, as well as the increase of the 
porosity increasing the availability of water (Bosa et al., 2003; Brahm et al., 2013), since all the substrates were enriched with nutrients in the environment after sterilization. This, providing the best ability in root formation can also be attributed to aeration and moisture retention due to the high availability of the raw material in the regions (Cardoso et al., 2011; Freitas et al., 2013).

Table 3. Percentage of survival (PS), mean leaf number (NL), mean height of seedlings (HS), dry matter of aerial part (DMAP) and roots (DMR) and total dry matter (TDM) in acclimatization of micropropagated minirose seedlings on different substrates

\begin{tabular}{|c|c|c|c|c|c|c|}
\hline Substrates & PS & NL & HS & DMAP & DMR & TDM \\
\hline & \multicolumn{2}{|c|}{----- \% ----- } & ----- cm ----- & \multicolumn{3}{|c|}{ |--------------------------- g --------------------------- } \\
\hline DCP & $62.5 \mathrm{~b}^{*}$ & $19 \mathrm{ab}$ & $8.77 \mathrm{ab}$ & $2.02 \mathrm{ab}$ & $1.49 \mathrm{~b}$ & $3.51 \mathrm{c}$ \\
\hline $75 \% \mathrm{DCP}+25 \% \mathrm{RH}$ & $66.6 \mathrm{~b}$ & $20 \mathrm{a}$ & $8.89 \mathrm{ab}$ & $2.16 \mathrm{ab}$ & $1.55 \mathrm{ab}$ & $3.71 \mathrm{~b}$ \\
\hline $50 \% \mathrm{DCP}+50 \% \mathrm{RH}$ & $72.9 \mathrm{~b}$ & $20 \mathrm{a}$ & $9.13 \mathrm{a}$ & $2.28 \mathrm{a}$ & $1.63 \mathrm{a}$ & $3.93 \mathrm{a}$ \\
\hline $75 \% \mathrm{DCP}+25 \% \mathrm{CRH}$ & $100 \mathrm{a}$ & $17 \mathrm{ab}$ & $7.81 \mathrm{ab}$ & $2.17 \mathrm{ab}$ & $1.54 \mathrm{ab}$ & $3.71 \mathrm{~b}$ \\
\hline $50 \% \mathrm{DCP}+50 \% \mathrm{CRH}$ & $100 \mathrm{a}$ & $16 \mathrm{ab}$ & $7.00 \mathrm{ab}$ & $2.06 \mathrm{ab}$ & $1.51 \mathrm{~b}$ & $3.57 \mathrm{~b}$ \\
\hline $100 \% \mathrm{~V}$ & $60.4 \mathrm{~b}$ & $13 \mathrm{~b}$ & $5.99 \mathrm{~b}$ & $1.95 \mathrm{~b}$ & $1.47 \mathrm{~b}$ & $3,42 \mathrm{c}$ \\
\hline $50 \% \mathrm{~V}+50 \% \mathrm{DCP}$ & $77.0 \mathrm{ab}$ & $18 \mathrm{ab}$ & $8.14 a b$ & $2.21 \mathrm{ab}$ & $1.56 \mathrm{ab}$ & $3.77 \mathrm{~b}$ \\
\hline B & $83.3 \mathrm{ab}$ & $14 \mathrm{ab}$ & $8.29 \mathrm{ab}$ & $2.16 \mathrm{ab}$ & $1.50 \mathrm{~b}$ & $3.67 \mathrm{~b}$ \\
\hline $75 \% \mathrm{R}+25 \% \mathrm{DCP}$ & $85.4 \mathrm{ab}$ & $16 \mathrm{ab}$ & $8.29 \mathrm{ab}$ & $2.13 \mathrm{ab}$ & $1.53 \mathrm{ab}$ & $3.66 \mathrm{~b}$ \\
\hline $50 \% \mathrm{R}+50 \% \mathrm{DCP}$ & $72.9 \mathrm{~b}$ & $14 \mathrm{ab}$ & $6.05 \mathrm{~b}$ & $2.05 \mathrm{ab}$ & $1.57 \mathrm{ab}$ & $3.62 \mathrm{~b}$ \\
\hline C.V. $(\%)$ & 13.32 & 17.49 & 15.43 & 6.66 & 3.07 & 4.62 \\
\hline
\end{tabular}

Note. ${ }^{*}$ Averages followed by equal letters in the column are statistically the same, at the 5\% probability level, by the Turkey test.

The dry matter yield of the minirose seedlings varied (1.95 g to $2.28 \mathrm{~g})$ among the evaluated substrates. The substrates that used the dry coconut powder in their blends were the highest results. The formulation of the substrate $50 \%$ of dry coconut powder plus $50 \%$ of rice husk obtained the highest yield of dry matter of the aerial part (2.28 g) differing only from the treatment with vermiculite in which the lowest value of $(1.95 \mathrm{~g})$. The higher carbon partition for the leaves increases leaf area index, resulting in a large interception of light and increasing the amount of dry matter accumulated (Santos et al., 2015). This relationship is crucial in the adequacy of the photosynthetic activity of plants produced in vitro. According to Dias et al. (2014), in vitro plants exhibit photosynthesis activity, but when they move to an autotrophic environment they are only able to control transpiration and reduce water loss when well developed. These results agree with the values found for the number of leaves and heights of the minirose seedlings evaluated in the experiment. The addition of the rice husk to the coconut powder improves the characteristics of the substrate compared to the other treatments that used dry coconut powder in its formulations, providing a better development of the minirose seedlings. These results also bring advantages from the productive and economical points of view: the best production results were obtained by mixing the substrates, second Zorzeto et al. (2016), whose composition reduces the amount of coconut fiber needed in $50 \%$ of the total volume, representing a producer economy.

The dry matter of the roots of the minirose seedlings ranged from $1.47 \mathrm{~g}$ to $1.63 \mathrm{~g}$, showing a higher development of the root system in the seedlings where the substrate used was dry coconut powder mixed with rice husk, charred rice husk or with washed sand of river. Addition of these materials of different diameters, the mixture improved the physical characteristics of the dry coconut powder used alone together with the vermiculite and the Bioplant ${ }^{\circledR}$ the lowest results of root dry matter $(1.49 \mathrm{~g}, 1.47 \mathrm{~g}$ and $1.50 \mathrm{~g}$ respectively). Corroborating with results obtained by Kratz et al. (2012), worked with eucalyptus where they verified that differences in the diameter of the particles of the rice husk and the carbonized rice hull influence the aeration of the substrates in which they are used in the formulation, thus facilitating the development of the roots.

The total dry matter of the minirose seedlings varied from $3.42 \mathrm{~g}$ to $3.93 \mathrm{~g}$ among the different substrates used in their acclimatization. The formulation $50 \%$ dry coconut powder more $50 \%$ rice husk favored the development of the aerial part as well as the root system of the minirose seedlings. Statistically differentiating from other substrates such as Bioplant ${ }^{\circledR}$ or others that used dry coconut powder in its formulation. The vermiculite and dry coconut powder used without mixing with any other material had the lowest total dry matter yield results, in agreement with the other results found for the development of the minirose in the experiment. For vermiculite, 
the low performance as a substrate may be related to its high content of magnesium and iron which may have affected the calcium magnesium ratio of the medium and absorption of calcium and other nutrients by the plant. Caldeira et al. (2013) suggest that vermiculite needs balancing of essential nutrients and should be used in conjunction with other material, preferably of organic origin, in order to promote aeration and porosity to other less porous substrates, in agreement with the results found in the experiment, where the addition of dry coconut powder to vermiculite promoted better results in the analyzed characteristics when compared to the use of vermiculite substrate without addition of other materials.

The use of carbonized rice husk as a substrate should also be observed carefully since it favors good conditions for the survival of the minirose seedlings, however, the increase of its proportion in the formulation favors the reduction of the values of the characteristics evaluated in the experiment. According to Rota and Pauletti (2008), evaluating the use of carbonized rice husk in different blends with peat-based commercial substrate, they observed that the addition of more than $50 \%$ of carbonized rice husk to the substrate raises the $\mathrm{pH}$ value too much the development of seedlings.

The Bioplant ${ }^{\circledR}$ substrate showed inferior results for the percentage of survival and the development of the minirose seedlings. Statistical difference for root dry matter and total dry matter of the seedlings. These results are different from those found by Gomes et al. (2008) found the highest results for the development of lettuce seedlings when using Bioplant $\AA$ as a substrate and by Dutra et al. (2013) when using alternative substrates in the production of canafístula seedlings. The difference of results can be related to the commercial substrate favoring the densification that hinders the growth of the root system of the micropropagated seedlings of minirose since the developed roots are very weak and sensitive when compared the roots developed by the lettuce, damaging the absorption of essential nutrients to the development of seedlings.

In general, taking into account all the characteristics evaluated, the substrates that presented the best results in descending order were: $50 \%$ dry coconut powder more $50 \%$ rice husk $>75 \%$ dry coconut powder more $25 \%$ charcoal rice husk $>75 \%$ Sand more than $25 \%$ dry coconut powder $>75 \%$ dry coconut powder more $25 \%$ carbonized rice husk $>50 \%$ dry coconut powder $50 \%$ more $>50 \%$ vermiculite plus $50 \%$ dry coconut powder $>$ $50 \%$ more sand $50 \%$ dry coconut powder $>$ Bioplant ${ }^{\circledR}>$ dry coconut powder $>$ vermiculite.

\section{Conclusions}

The regional substrates of the Brazilian Northeast and their tested mixtures presented a viable alternative in the acclimatization and the development of minirose seedlings (Rosa chinensis 'Minima').

Dry coconut powder as a substrate should be used in mixtures with other materials to provide better conditions for acclimatization and development of minirose seedlings.

The carbonized rice hulls have good characteristics in acclimatization, and the amount used in the substrate formulation must be observed, since their increase reduces the development of the minirose seedlings.

The use of $50 \%$ dry coconut powder more $50 \%$ rice husk provides a better development of seedlings in minirose acclimatization (Rosa chinensis 'Minima').

\section{References}

Bosa, N., Calvete, E. O., Nienow, A. A., \& Suzin, M. (2003). Enraizamento e aclimatização de plantas micropropagadas de gipsofila. Horticultura Brasileira, 21(2), 207-210. https://doi.org/10.1590/S0102-053 62003000200017

Braga, F. T., Pasqual, M., Castro, E. M., Rafael, G. C., Favero, A. C., \& Valente, T. C. T. (2011). Alterações morfofisiológicas de plantas de abacaxizeiro influenciadas por diferentes substratos durante o processo de aclimatização. Ciência e Agrotecnologia, 35(5), 863-868. https://doi.org/10.1590/S1413-7054201100 0500001

Caldeira, M. V., Delarmelina, W. M., Peroni, P., Gonçalves, E. O., \& Silva, A. G. (2013). Lodo de esgoto e vermiculita na produção de mudas de eucalipto. Revista Pesquisa Agropecuária Tropical, 43(2), 155-163. https://doi.org/10.1590/S1983-40632013000200002

Cardoso, C., Yamamoto, L. Y., Petri, E. A., Assis, A. M., Neves, C. S. V. J., \& Roberto, S. R. (2011). AIB e substratos no enraizamento de estacas de pessegueiro 'Okinawa' coletadas no outono. Semina: Ciências Agrárias, 32(4), 1307-1314. https://doi.org/10.5433/1679-0359.2011v32n4p1307

Dias, G. M. G., Soares, J. D. R., Pasqual, M., Silva, R. A. L., Rodrigues, L. C. A., Pereira, F. J., \& Castro, E. M. (2014). Photosynthesis and leaf anatomy of Anthurium cv. Rubi plantlets cultured in vitro under different 
silicon (Si) concentrations. Australian Journal of Crop Science, 8, 1160-1167. Retrieved from http://www.cropj.com/dias_8_8_2014_11

Diniz, J. D. N., Almeida, J. L., Oliveira, A. B., \& Vidal, F. R. (2014). Multiplicação e enraizamento in vitro de Minirosa. Revista Ciência Agronômica, 45(1), 68-73. https://doi.org/10.1590/S1806-66902014000100009

Dutra, R. T., Massad, M. D., Sarmento, M. F. Q., \& Oliveira, J. C. (2012). Emergência e crescimento inicial da canafístula em diferentes substratos e métodos de superação de dormência. Revista Caatinga, 25(2), 65-71. Retrieved from https://periodicos.ufersa.edu.br/index.php/caatinga/article/view/2243/pdf

Dutra, T. R., Massad, M. D., Sarmento, M. F. Q., \& Oliveira, J. C. (2013). Substratos alternativos e métodos de quebra de dormência para produção de mudas de canafístula. Revista Ceres, 60(1), 72-78. https://doi.org/ 10.1590/S0034-737X2013000100011

Fermino, M. H., Gonçalves, R. S., Battistin, A., Silveira, J. R. P., Busnello, A. C., \& Trevisam, M. (2010). Aproveitamento dos resíduos da produção de conserva de palmito como substrato para plantas. Horticultura Brasileira, 28(3), 282-286. https://doi.org/10.1590/S0102-05362010000300007

Ferreira, E. A., Chirinéia, C. F., Pasqual, M., Martins, A. D., \& Soares, J. D. R. F. (2014). In M. Pasqual, \& E. A. Chagas (Eds.), Cultura de tecidos em espécies frutiferas (pp. 80-81). Boa Vista, UFRR.

Freitas, De G. A., Silva, Da R. R., Barros, H. B., Vaz-De-Melo, A., \& Abrahão, A. P. (2013). Produção de mudas de alface em função de diferentes combinações de substratos. Revista Ciência Agronômica, 44(1), 159-166. https://doi.org/10.1590/S1806-66902013000100020

Gomes, L. A. A., Rodrigues, A. C., Collier, L. S., \& Feitosa, S. Dos S. (2008). Produção de mudas de alface em substrato alternativo com adubação. Horticultura Brasileira, 26(3), 359-363. https://doi.org/10.1590/ S0102-05362008000300013

Iarema, L., Cruz, A. C. F. C., Saldanha, C. W., Dias, L. L. C., Vieira, R. F., Oliveira, E. J., \& Otoni, W. C. (2012). Photoautotrophic propagation of Brazilian ginseng [Pfaffia glomerata (Spreng.) Pedersen]. Plant Cell, Tissue and Organ Culture, 110(2), 227-238. https://doi.org/10.1007/s11240-016-1089-z

Junqueira, A. H., \& Pettz, M. S. (2014). O setor produtivo de flores e plantas ornamentais do Brasil, no período de 2008 a 2013: Atualizações, balanços e perspectivas. Revista Brasileira de Horticultura Ornamental, 20(2), 115-120. https://doi.org/10.14295/rbho.v20i2.727

Klein, C. (2015). Utilização de substratos alternativos para produção de mudas. Revista Brasileira de Energias Renováveis, 4, 43-63. https://doi.org/10.1590/S0034-737X2011000300016

Kratz, D., Wendling, I., \& Pires, P. P. (2012). Miniestaquia de Eucalyptus benthamii $\times$ E. dunnii em substratos a base de casca de arroz carbonizada. Revista Scientia Forestalis, 40(96), 547-556. Retrieved from http://www.alice.cnptia.embrapa.br:doc/943585

Kratz, D., Wendlling, I., Nogueira, A. C., \& Zouza, P. V. (2013). Propriedades físicas e químicas de substratos renováveis. Revista Árvore, 37(6), 1103-1113. https://doi.org/10.1590/S0100-67622013000600012

Lopes, G. E. M., Vieira, H. D., Jasmim, J. M., Shimoya, A., \& Marciano, C. R. (2011). Casca do fruto da mamoneira como substrato para as plantas. Revista Ceres, 58(3), 350-358. https://doi.org/10.1590/ S0034-737X2011000300016

Mitsueda, N. C., Costa, E. V. Da, \& Oliveira, P. S. D. (2011). Aspectos Ambientais do Agronegócio Flores e Plantas Ornamentais. Revista em Agronegócios e Meio Ambiente, 4(1), 9-20. Retrieved from http://periodicos.unicesumar.edu.br/index.php/rama/article/view/617/1183

Ramos, A. R. P., Dias, R. De C. S., Aragão, C. A., \& Mendes, A. M. S. (2012). Mudas de melancia produzidas com substrato à base de pó de coco e soluções nutritivas. Horticultura Brasileira, 30(2), 339-344. https://doi.org/10.1590/S0102-05362012000200026

Rota, L. D., \& Pauletti, G. F. (2008). Efeito da adição de casca de arroz em substrato comercial a base de turfa na produção de mudas de Viola tricolor L. Revista Brasileira de Agrociência, 14(3-4), 45-48. Retrieved from http://www2.ufpel.edu.br/faem/agrociencia/v14n3/artigo06.pdf

SAEG. (2007). Sistema para Análises Estatísticas (V. 9.1). Fundação Arthur Bernardes, UFV, Viçosa.

Santos, L. A., Soratto, R. P., Fernandes, A. M., \& Gonsales, J. R. (2015). Crescimento, índices fisiológicos e produtividade de cultivares de feijoeiro sob diferentes níveis de adubação. Revista Ceres, 62(1), 107-116. https://doi.org/10.1590/0034-737X201562010014 
Schuck, M. R., Lipski, B., Silva, A. L. L., Carvalho, D. C., \& Biasi, L. A. (2012). Aclimatização de plantas micropropagadas de videira cv. Bordô (Vitis labrusca L.) em diferentes substratos. Journal of Biotechnology and Biodiversity, 3(4), 2016-212.

Silva, A. T., Pasqual, M., Ishida, S. J., \& Antunes, L. E. C. (1995). Aclimatização de plantas provenientes da cultura in vitro. Pesquisa Agropecuária Brasileira, 30(1), 49-53. Retrieved from http://seer.sct.embrapa.br/ index.php/pab/article/view/4273/1559

Thakur, R. C., \& Karnosky, D. F. (2007). Micropropagation and germoplasma conservation of Central Park Splendor Chinese elm (Ulmus parvifolia) Jacq. 'A/Ross Central Park' trees. Plant Cell Reports, 26, 1171-1177. https://doi.org/10.1007/s00299-007-0334-7

Zorzeto, T. Q., Júnior, F. F., \& Dechen, S. C. F. (2016). Substratos de fibra de coco granulada e casca de arroz para a produção do morangueiro 'Oso Grande'. Bragantia, 75(2), 222-229. https://doi.org/10.1590/ $1678-4499.325$

\section{Copyrights}

Copyright for this article is retained by the author(s), with first publication rights granted to the journal.

This is an open-access article distributed under the terms and conditions of the Creative Commons Attribution license (http://creativecommons.org/licenses/by/4.0/). 